\title{
DAPATKAN PROVINSI PAPUA MENCAPAI KEMANDIRIAN PRODUKSI PADI ?
}

\author{
(CAN PAPUA PROVINCE ECHIEVE INDEPENDENCE OF PADDY PRODUCTION ?) \\ Richardo Franky Kristo Samderubun'1, Budiasih² \\ Proliteknis Statistika STIS \\ Badan Pusat Statistik \\ Alamat Korespondensi penulis pertama (Tahoma $10 \mathrm{pt}$ ) \\ E-mail: 15.8852@stis.ac.id
}

\begin{abstract}
ABSTRAK
Salah satu poin tujuan kedua SDGs adalah mencapai ketahanan pangan, khususnya beras di Indonesia. Seperti provinsi lain penghasil beras, Kabupaten Merauke yang merupakan sentra produksi beras di Provinsi Papua berupaya untuk meningkatkan produksi padi. Determinan produksi suatu usaha tidak lepas dari efisiensi teknis (ET) dan total faktor produktivitas (TFP) usaha bersangkutan. Efisiensi teknis menunjukan kemampuan unit usaha dalam menghasilkan output yang maksimum dari input yang tersedia. Sedangkan TFP adalah bagian dari output yang tidak bisa dijelaskan oleh seberapa besar jumlah input yang digunakan. Dengan demikian TFP merupakan indikator kualitas input. Tujuan penelitian ini adalah mengidentifikasi tingkat efisiensi teknis dan total faktor produktivitas usaha padi di provinsi Papua. Model yang digunakan adalah analisis regresi dan analisis stokhastik frontier. Hasil penelitian menunjukan bahwa usaha rumah tangga tanaman padi di Provinsi Papua belum efisien. Petani yang masuk dalam kelompok tani dan mengikuti penyuluhan pertanian akan meningkatkan TFP. Kesimpulannya adalah usaha padi di Provinsi Papua belum mampu mencapai kemadirian dalam memproduksi padi, karena penggunaan input belum mampu mencapai output maksimal. Disamping itu TFP petani perlu ditingkatkan.
\end{abstract}

Kata kunci: efisiensi teknis, total faktor produktivitas, analisis stokastik frontier, analisis regresi

\begin{abstract}
One point of the second goal of the SDGs is achieving food security, especially paddy in Indonesia. Like the other paddy producing provinces, Merauke Regency which is the center of paddy production in Papua Province is trying to increase their paddy production. The determinant of production cannot be separated from the technical efficiency (TE) and total factor productivity (TFP) of the business. Technical efficiency shows the ability of business units to produce maximum output from available inputs. Whereas TFP is part of the output that cannot be explained by the amount of input used. Thus, TFP is an indicator of input quality. The purpose of this study is to identify the level of technical efficiency and total factor productivity of paddy businesses in Papua Province. The model used is regression analysis and frontier stochastic analysis. The result shows that the paddy households in Papua Province were not efficient. Farmers who join the farmer groups and participate in agricultural counseling will increase TFP. The conclusion is that the paddy business in Papua Province has not been able to achieve independence in producing paddy, because the use of inputs has not been able to achieve maximum output. Beside, TFP of the farmer needs to be improved.
\end{abstract}

Keywords: thecnical efissienci, total factor productivity, stochastic frontier analysis, regression analysis 


\section{PENDAHULUAN}

ketersediaan bahan makanan pokok adalah tugas wajib pemerintah suatu daerah maupun suatu negara karena menyangkut hajat hidup orang banyak. Suistinabel Development goals tujuan kedua berbunyi "Mengakhiri kelaparan, mencapai ketahanan pangan dan nutrisi yang lebih baik dan mendukung pertanian berkelanjutan". Berdasarkan bunyi tujuan kedua dapat dikatakan bahwa adanya upaya yang dilakukan oleh masyarakat internasional guna mengatasi masalah kekurangan makanan dan gizi. pada point kedua tujuan kedua SDGs dapat dilihat bahwa dalam mengatasi masalah kekurangan makanan dan gizi, masyarakat internasional berupaya untuk merealisasikan katahanan pangan dunia. sejalan dengan upaya realisasi ketahanan pangan dunia, republik indonesia juga mengupayakan ketahanan pangan

Telah diketahui bersama bahwa makanan pokok masyarakat Papua adalah sagu yang biasa dikonsumsi oleh mayoritas masyarakat Papua pesisir dan umbi-umbian yang biasa dikonsumsi oleh mayoritas masyarakat Papua di daerah pegunungan. Pastor Eddy Kristiyanto OFM (2017, hal.19) menulis $^{1}$ di daerah Lembah Balim kesibukan utama masyarakan adalah mengelolah menanam talas (keladi), ubi jalar (hipere, patatas). Pastor Eddy Kristiyanto OFM (2017, hal.39) penghasilan masyarakat yang lain adalah sagu, ikan, pinang, noken, hasil kebun (patatas atau hiapre, talas) dan gaji sebagai karyawan swasta dan pemerintah. Pastor Eddy Kristiyanto OFM (2017, hal.41) menulis hanya pada satu atau dua jenis mata pencaharian hidup : sagu, ikan (Mimika), patatas (Paniai, Balim). Frans Ampofires pada tahun 2002 melakukan penelitian di Kabupaten Merauke menyatakan bahwa sagu merupakan makanan pokok yang dikonsumsi masyarakat, yang biasanya diselingi dengan makanan lain seperti pisang, talas, dan nasi yang merupakan makanan yang dikenal dan biasa dikonsumsi.

Kepala Divisi Regional Perum Bulog Papua, Achmad Kastela kepada ANTARA di Jayapura, pada hari Senin, 10 Januari 2012 mengakui beralihnya pola konsumsi masyarakat Papua itu sudah nampak jelas terlihat, baik itu dikalangan generasi muda maupun tua. "Namun hingga saat ini belum ada survei yang menyatakan berubahnya pola konsumsi masyarakat di Papua," ungkap Achmad Kastela seraya menambahkan beralihnya pola makan itu kemungkinan disebabkan beras selain lebih mudah diperoleh juga pengolahannya gampang. Pada tanggal 10 november 2016, Harian Nasional menulis : "Pemerintah Provinsi (Pemprov) Papua mengakui konsumsi beras per kapita penduduk di wilayahnya dari tahun ke tahun cenderung meningkat, sedangkan konsumsi pangan pokok lainnya seperti umbi-umbian dan sagu menurun. Masyarakat Papua saat ini lebih suka mengonsumsi beras sebagai makanan pokok dibanding sagu atau umbi-umbian". Berdasarkan tulisan-tulisan yang telah dipaparkan oleh Pastor A. Eddy Kristianto OFM hingga Pemerintah Provinsi Papua, maka dapat disimpulakan bahwa telah terjadi perubahan pola konsumsi makanan pokok masyarakat Papua pada umumnya, yang semula mengonsumsi sagu dan atau umbi-umbian menjadi beras. Tujuan dari penelitian ini adalah melihat tingkat efisiensi teknis dan mengetahui determinan total faktor produksi di provinsi papua pada tahun 2014.

Penelitian yang dilakukan oleh Pane dkk pada tahun 2018 yang berjudul Pengaruh Penyuluhan Pertanian Terhadap Produktivitas Padi Sawah (Oryza sativa L.) (Kasus: Desa Kerapuh, Kecamatan Dolok Masihul, Kabupaten Serdang Bedagai). Kesimpulan pada penelitian ini adalah Faktor pendidikan, lama berusahatani, program penyuluhan dan kompetensi penyuluh secara serempak berpengaruh nyata terhadap produktivitas di daerah penelitian.

Penelitian yang dilakuakan oleh Sutra Mandasari pada tahun 2018 yang berjudul Hubungan Peran Kelompok Tani dengan Produktivitas Usahatani Benih Padi (Studi Kasus : Kelompok Tani Surya Bangkit di Desa Mandalawangi, Kecamatan Sukasari, Kabupaten Subang). Kesimpulan pada penelitian ini adalah hasil analisis di lanpangan menunjukan bahwa tidak terdapat hubungan antara kelompok tani surya Bangkit dan produktivitas usahatani benih padi.

${ }^{1}$ Penulisan yang dilakukan berdasarkan sejaran 50 Tahun Keuskupan Jayapura yakni dari Tahun 1966-2016.

$$
\text { TFP }_{i}=\beta_{0}+\beta_{1} J K_{i}+\beta_{2} \text { Usia }_{i}+\beta_{3} \text { Penyu }_{i}+\beta_{4} \text { Keltan }_{i}
$$


Penelitian yang dilakukan oleh Agus Yuniawan Isyanto pada tahun 2018 yang berjudul FaktorFaktor yang Berpengaruh Terhadap Produktivitas Usahatani Mina Padi Di Kota Tasikmalaya. Kesimpulan pada penelitian ini adalah Umur dan Pendidikan berpengaruh signifikan terhadap produktivitas usahatani minapadi, sedangkan pengalaman, ukuran keluarga dan jenis kelamin tidak berpengaruh signifikan terhadap produktivitas usahatani minapadi.

\section{METODE}

Soekartawi (2003) menyatakan fungsi produksi Cobb-Douglas adalah suatu fungsi atau persamaan yang melibatkan dua atau lebih variabel, dimana variabel yang satu disebut dengan variabel dependen, yang dijelaskan, $(Y)$, dan yang lain disebut variabel independen, yang menjelaskan, $(\mathrm{X})$. secara matematik, fungsi Cobb-Douglas dapat ditulis (walter Nicholson) :

$$
\begin{aligned}
& Q= f(K, L)=A K^{a} L^{b} \\
& \text { dimana : } \\
& \mathrm{Q}=\text { quantitas output } \\
& \mathrm{K}=\text { modal } \\
& \mathrm{L}=\text { tenaga kerja } \\
& \mathrm{a}, \mathrm{b}=\text { besaran yang diduga }
\end{aligned}
$$

Coelli dkk (2005) menyatakan ketika kita mengacu pada produktivitas, kita mengacu pada total faktor productivitas, yang merupakan ukuran produktivitas yang melibatkan semua faktor produksi. Guna menghitung TFP maka dilakukan penurunan rumus dari fungsi produksi Cobb-Douglass sebagai berikut.

$$
T F P=A=\frac{Y}{K^{a} L^{b}}
$$

Salah satu metode yang digunakan untuk mengestimasi efisiensi teknis adalah analisis stokastik frontier. Spesifikasi model analisis deterministic frontier mengabaikan fakta bahwa output dapat dipengaruhi oleh guncangan acak atau noise yang tidak berada di bawah kendali produsen. Oleh karena itu memasukkan guncangan acak spesifik produsen ke dalam analisis memerlukan spesifikasi fungsi produksi stokastik frontier. Oleh karena itu dibuatlah persamaan fungsi produksi stokastik frontier sebagai berikut.

$$
y_{i}=f\left(x_{i} ; \beta\right) \exp \left\{v_{i}\right\} . E T_{i}
$$

di mana $[f(x i ; \beta) . \exp \{v i\}]$ adalah produksi stokhastik frontier. Produksi stokhastik frontier terdiri dari dua bagian: bagian deterministik $f(x i ; \beta)$ umum untuk semua produsen dan produsen khusus bagian $\exp \{v i\}$, yang menangkap efek guncangan acak pada setiap produsen. Maka untuk menghitung efisiensi teknis menggunakan analisis stokastik frontier dibuatlah rumus berikut.

$$
E T_{i}=\frac{y_{i}}{f\left(x_{i} ; \beta\right) \cdot \exp \left\{v_{i}\right\}}
$$

Persamaan diatas mendefinisikan efisiensi teknis sebagai rasio output yang diamati terhadap output layak maksimum dalam lingkungan yang ditandai oleh $\exp \left\{v_{i}\right\} . y_{i}$ mencapai nilai layak maksimumnya $\left[f\left(x_{i} ; \beta\right) . \exp \left\{v_{i}\right\}\right]$ jika, dan hanya jika $T E_{i}=1$. Jika tidak, $T E_{i}<1$ memberikan ukuran kekurangan output yang diamati dari output layak maksimum di lingkungan yang ditandai oleh $\exp \left\{v_{i}\right\}$, yang diizinkan bervariasi di antara produsen.

Aigner, Lovell and Schmidt (1977) dan van den Broeck (1977) dalam Coelli dkk (2005; .242) secara independen mengusulkan model fungsi produksi frontier stokastik dalam bentuk

$$
\ln Q_{i}=x_{i}^{\prime} \beta+v_{i}-u_{i}
$$

Fitur-fitur penting dari model stokastik frontier dapat digambarkan secara grafis. Untuk melakukannya dengan cara yang memudahkan analisis maka dibatasi perhatian pada perusahaan yang menghasilkan $Q_{i}$ output yang hanya menggunakan satu input x. Dalam penggambaran dalam grafis menggunakan model stokastik frontier Cobb-Douglas yang mengambil bentuk: 
atau

$$
\ln q_{i}=\beta_{0}+\beta_{1} \ln x_{i}+v_{i}-u_{i}
$$

atau

$$
\begin{aligned}
& q_{i}=\exp \left(\beta_{0}+\beta_{1} \ln x_{i}+v_{i}-u_{i}\right) \\
& q_{i}=\exp \left(\beta_{0}+\beta_{1} \ln x_{i}\right)+\exp \left(v_{i}\right) \times \exp \left(-u_{i}\right) \\
& \begin{array}{c}
\text { Komponen } \\
\text { deterministik }
\end{array} \text { noise Inefisiensi }
\end{aligned}
$$

Model yang digunakan adalah analisis regresi dan analisis stokhastik frontier. Model yang digunakan untuk melihat deteminan efisiensi teknis rumah tangga usaha tanaman padi yang mengusahakan padi varietas Inbrida adalah sebagai berikut.

$$
\ln V P_{i}=\beta_{0}+\beta_{1} \ln X 1_{i}+\beta_{2} \ln X 2_{i}+\beta_{3} \ln X 3_{i}+v_{i}-u_{i}
$$

dimana persamaan tersebut adalah persamaan fungsi produksi stochastic frontier yang digunakan untuk mengestimasi efisiensi teknis. Sedangkan persamaan yang dibawah ini adalah model maximum likelihood yang digunakan melihat determinan efisiensi teknis rumah tangga usaha tanaman padi yang mengusahakan padi varietas Hibrida, Inbrida, dan Ladang.

$$
E T_{i}=\delta_{0}+\delta_{1} Z_{1 i}+\delta_{2} Z_{2 i}+\delta_{3} Z_{3 i}+\delta_{4} Z_{4 i}+\delta_{5} Z_{5 i}+\delta_{6} Z_{6 i}+\delta_{7} Z_{7 i}+\delta_{8} Z_{8 i}+w_{i}
$$

Keterangan :

$V P=$ volume produksi

$Z_{3}=$ dummy pendidikan terakhir yang ditamatkan KRT

$X_{1}=$ penggunaan bibit

$Z_{4}=$ dummy pola tanam

$X_{2}=$ penggunaan pupuk

$Z_{5}=$ dummy alat produksi

$X_{3}=$ tanaga kerja

$Z_{6}=$ dummy menerima bantuan

$E T_{i}=$ efisiensi teknis

$Z_{7}=$ dummy mengikuti penyuluhan

$Z_{1} \quad=$ dummyjenis kelamin

$Z_{8}=$ dummy mengikuti kelompok tani

Berikutnya, model yang digunakan untuk mengestimasi Total Factor Productivity (TFP) padi Inbrida adalah

$$
\ln V P_{i}=\beta_{0}+\beta_{1} \ln X 1_{i}+\beta_{2} \ln X 2_{i}+\beta_{3} \ln X 3_{i}
$$

\section{HASIL DAN PEMBAHASAN}

Rata-rata efisiensi teknis rumah tangga usaha tanaman padi yang mengusahakan padi varietas Inbrida di Provinsi Papua pada tahun 2014 adalah sebesar 59,66 persen. Makna dari angka rata-rata tersebut adalah rumah tangga usaha tanaman padi yang mengusahakan padi varietas Inbrida secara rata-rata telah mampu memproduksi sebesar 59,66 persen dari volume produksi optimum yang dimiliki berdasarkan input yang tersedia.

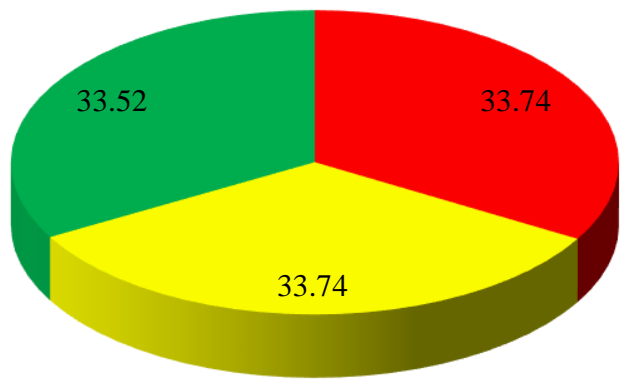

Efisiensi Teknis Rendah

Efisiensi Teknis Sedang

- Efisiensi Teknis Tinggi

Sumber : Output FRONTIER 4.1

Gambar 1. Persentase rumah tangga usaha tanaman padi yang mengusahakan padi varietas inbrida berdasarkan klasifikasi efisiensi teknis 
Berdasarkan Gambar 1 dapat dilihat bahwa persentase rumah tangga usaha tanaman padi yang mengusahakan padi varietas Inbrida yang memiliki efisiensi teknis tinggi di Provinsi Papua pada tahun 2014 sebesar 33,52 persen. Besarnya persentase rumah tangga usaha tanaman padi yang mengusahakan padi varietas Inbrida yang memiliki efisiensi teknis sedang di Provinsi Papua pada tahun 2014 sebesar 33,74 persen. Sedangkan persentase rumah tangga usaha tanaman padi yang mengusahakan padi varietas Inbrida yang memiliki efisiensi teknis rendah di Provinsi Papua pada tahun 2014 sebesar 33,74 persen. Berdasarkan Gambar 39 dapat dilihat bahwa mayoritas rumah tangga usaha tanaman padi yang mengusahakan padi verietas Inbrida di Provinsi Papua memiliki efisiensi teknis yang sedang hingga rendah.

Tabel 1. Determiinan Total Faktor Produktivitas Rumah Tangga Usaha Tanaman padi yang mengusahakan padi varietas Inbrida

\begin{tabular}{|l|r|r|r|c|}
\hline Variabel & \multicolumn{1}{|c|}{ Koefisien } & \multicolumn{1}{l|}{ Std.Error } & \multicolumn{1}{c|}{ t hitung } & Peluang \\
\hline (Intercept) & 9,294 & 3,107 & 2,991 & $0,00323^{*}$ \\
\hline Jenis Kelamin & $-3,686$ & 2,268 & $-1,625$ & 0,10613 \\
\hline Penyuluhan Pertanian & 3,301 & 1,148 & 2,876 & $0,00458^{*}$ \\
\hline Kelompok Tani & 7,685 & 1,652 & 4,652 & $0,0000^{*}$ \\
\hline
\end{tabular}

Berdasarkan Tabel 1 dapat dilihat bahwa variabel yang signifikan mempengaruhi total faktor produktivitas adalah variabel mengikuti penyuluhan pertanian dan variabel mengikuti kelompok tani. Arah hubungan TFP padi varietas Inbrida dan dummy jenis kelamin kepala rumah tangga usaha tanaman padi yang mengusahakan padi varietas Inbrida adalah negatif Jika jenis kelamin kepala rumah tangga usaha tanaman padi yang mengusahakan varietas Inbrida adalah laki-laki, maka TFP padi varietas Inbrida pada rumah tangga tersebut akan lebih rendah jika dibandingkan dengan kepala rumah tangga usaha tanaman padi yang mengusahakan varietas Inbrida yang berjenis kelamin perempuan. Hubungan antara TFP dan jenis kelamin kepala rumah tangga tanaman padi yang mengusahakan padi Inbrida pada penelitian ini tidak sejalan teori dengan penelitian yang dilakukan oleh Agus Yuniawan Isyanto pada tahun 2018.

Arah hubungan TFP dan dummy mengikuti penyuluhan pada varietas Inbrida adalah positif dan signifikan. Jika ada anggota rumah tangga usaha tanaman padi varietas Inbrida yang mengikuti penyuluhan maka, efiseinsi teknis dari rumah tangga tersebut akan lebih rendah jika dibandingkan dengan rumah tangga usaha tanaman padi yang tidak mengikuti penyuluhan. Namun, dari interpretasi tersebut menurut peneliti tidak dapat diinterpretasikan bahwa rumah tangga usaha tanaman padi tidak boleh mengikuti penyuluhan agar TFP dari rumah tangga tersebut meningkat. Pengaruh dummy mengikuti penyuluhan yang signifikan dan negatif terhadap TFP rumah tangga usaha tanaman padi yang mengusahakan padi varietas inbrida pada penelitian ini sejalan dengan pernyataan Pane dkk pada tahun 2018.

Arah hubungan TFP rumah tangga usaha tanaman padi yang mengusahakan padi varietas Inbrida dan dummy mengikuti kelompok tani adalah positif dan signifikan. Jika ada anggota rumah tangga usaha tanaman usaha tanaman padi yang mngusahakan padi varietas Inbrida yang mengikuti kelompok tani, maka TFP rumah tangga tersebut akan menurun. Pengaruh negatif dummy mengikuti kelompok tani terhadap TFP rumah tangga usaha tanaman padi yang mengusahakan padi varietas Inbrida pada penelitian ini sejalan dengan penelitian yang dilakukan oleh Sutra Mandasari pada tahun 2018.

\section{KESIMPULAN}

Kesimpulan pada penelitia ini adalah rumah tangga usaha tanaman padi yang mengusahakan padi varietas padi Inbrida belum mencapai volume produksi yang masimum dari input yang tersedia. Serta variabel yang signifikan mempengaruhi total faktor produktivitas adalah variabel mengikuti penyuluhan pertanian dan variabel mengikuti kelompok tani. 


\section{DAFTAR PUSTAKA}

Pane, Mutiara., Kesuma, Sinar Indra., Nasution, Siti Khadijah (2018), PENGARUH PENYULUHAN PERTANIAN TERHADAP PRODUKTIVITAS PADI SAWAH (Oryza sativa L.) (Kasus: Desa Kerapuh, Kecamatan Dolok Masihul, Kabupaten Serdang Bedagai) JOURNAL ON SOCIAL ECONOMIC OF AGRICULTURE AND AGRIBUSINESS Vol 9, No 12,

Isyanto, Agus Yuniawan (2018), FAKTOR-FAKTOR YANG BERPENGARUH TERHADAP PRODUKTIVITAS USAHATANI MINA PADI DI KOTA TASIKMALAYA,

Coelli, T. J., Rao, D. P., O'Donnell, C. J., \& Battase, G. E. (2005). An Introduction To Efficiency and Productivity Analysis $2^{\text {nd }}$ edition. New York: Springer.

Soekartawi. (2003). Teori Ekonomi Produksi : Dengan Pokok Pembahasan Analisis Fungsi Cobb-Douglas. Jakarta: RajaGrafika Persada.

Khumbakar, S. C., \& Lovell, C. A. (2000). Stochastic Frontier Analysis. Cambridge: Cambridge University Press. 